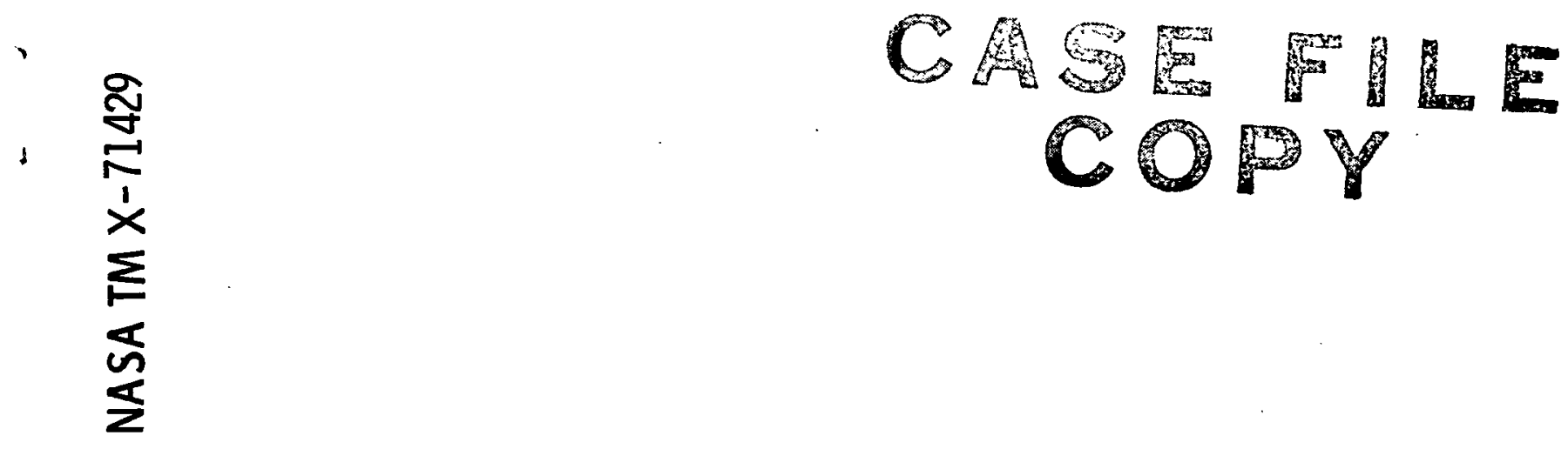

\title{
ODOR INTENSITY AND CHARACTERIZATION STUDIES \\ OF EXHAUST FROM A TURBOJET ENGINE COMBUSTOR
}

by Helmut F. Butze and David A. Kendall

Lewis Research Center

Cleveland, Ohio

1 TECHNICAL PAPER proposed for presentation at Ninth Propulsion Conference cosponsored by the American Institute of Aeronautics and Astronautics and the Society of Automotive Engineers

Las Vegas, Nevada, November 5 - 7, 1973 


\title{
ODOR INTEANSITY AND CHARACTERIZATION STUDIES OF EXXHAUST FROM A TURBONET ENGINE CONBUSTOR
}

\author{
Helmut F. Butze and Davld A. Kendall* \\ National Aeronautics and Space Administration \\ Lew1s Research Center \\ Clevelend, Oh10
}

\begin{abstract}
Sensory odor tests of the exhaust from a turbojet combustor operating at simulated lale conditlons were made by a human panel snlffing diluted exhaust gas. Simultaneously, samples of unilituted exhaust gas were collected on adsorbent substrates, subsequently removed by solvent flushing, and analyzed chemically by liquid chromatographic methods. The concentrations of the principal malodorous species, the aromatic (unburned fuel-related) and the oxygenated (partially burned fuel) fractions, as determined chromatographically, correlated well with the intenglty of the odor as determined by sniffing. Odor Intensity Increased as combustion efficiency decreased. Combustor modffications which increased combustion efficiency decreased odor intensity.

\section{Introduction}

This report presents the results of an invest1gation designed to determine the 1ntensity and character of the odor of gas turbine combustor exhaust gases. The project was carrled out under NASA contract NAS 3-1570I (1) by Arthur D. Little, Inc. in cooperation whth the Lewls Research Center of the National Aeronaut1cs and Space Administration. The main part of the experimental effort was conducted at the Lewls Research Center in Cleveland.

Although the problem of pollutant emissions from all sorts of fossil-fuel burning sources has recelved considerable attention over a number of years, concern over the contribution of aircraft to the overall pollution picture has only been voiced in recent years. Since intensity of odor is an aspect of pollution at airports that is readily sensed by the general public, the study of odor problems resulting from the operation of jet alrcraft is a very timely one. However, before the odor problems can be attacked vigorously, a method must be established for determining the intensity of malodorous emissions, both at the source and under ambient conditions after dilution.
\end{abstract}

During the past few years Arthur D. Little Inc., has studied the problem of exhaust odor from Diesel engines (2-5) and has developed techniques wh1ch make it possible to characterize the intensity of Diesel exhaust odor from both a sensory and an analytical standpoint. The scope of the present 10vestigation was to adapt the methodology developed for Diesel exhaust to the problem of jet combustor exhaust and to obtain data from a slngle turbojet combustor over a range of operating conditions with a number of different fuels and with several combustor modifications. Odor intensity evaluations were made both by a human panel sniffing and rating diluted exhaust gas and by means of analyticel technlques designed to measure the concentrations of the malodorous components.

\section{Odor Measuring Technlques}

In Its work with Diesel exhaust A. D. Little, Inc. had pursued two different approaches for deter- mining odor intensity. They were: (1) a human panel sniffing samples of diluted exhaust gas under controlled environmental conditions, and (2) chromatograph1c separation and analyses of exhaust gas to determine the concentration of the malodorous species. These tests hed shown that the concentrations of the oxysenated species, as determined by chromatography, correlated well with the 1ntensity of odor as determined by the odor panel.

To make sensory odor tests for turbojet engine combustors it was necessary to construct an odor room at the test facility and to train a panel of Lewis personnel to recogaize and rate odor intensity and character. To make analytical determinations it was necessary to collect sufficfently large volumes of exhaust gas so that the concentrations of the malodorous species could be readily measured with the existing andiytical technlques. Previous experlence had shown that large volumes of exhaust gas (as much as 500 ilters) can be collected in speclally prepared traps contalning adsorbent substrates and later removed from the substrates by reverse plushing with organic solvents. The traps are 1111 . ed with solld adsorbent materials (chromosorb 102, a cross linked polystyrene porous adsorbent) which allow the low molecular-welght gases to pass through, but retain most of the high molecular-weight organic compounds containing the malodorous species. The effluent gases from the traps have no significant odor. A schematic diagram showing the various steps employed in the odor tests is presented in figure 1.

Sensory tests. The odor test facility consisted of an air-conditioned chamber approximately 2.4 meters wide, 3.6 meters long, and 2.4 meters high. A manifold with four sniffing ports was located at the rear wall of the chamber. The sniffing ports were normally sealed with a hinged alumisum plate and a deodorized rubber gasket. A hole was cut in each gasket shaped to acconmodate the analyst' 8 face such that the nose was in the airstream while the face was pressed against the gasket to minimize Plow of dilution air into the manifold. Diluted exhaust gas, with dilution ratios ranging from 6600:1 to epproximately 280:1 was constantly circulated through the madifold. Normally five concentrations, each approximately double the previous one, were examined by the panel. The odor chamber and its associated dilution equipment are show schematically in figure 2 while a photograph of the panel in action is shown in figure 3 .

The panelists were trained by A. D. Iittle, Inc. personnel to recognize and rate odors according to the intensity scale presented in figure 4. In ada1tion to the intensity ratings the panel was asked to describe the character of the odor, using terms such as olly, kerosene like, smoky, burnt etc.

The odor intensity ratings thus obtained were then plotted against concentration on a semilogarithmic plot as ghown in figure 5. The odor intensity at a dilution ratio of 1000:1 is termed the

\footnotetext{
*Arthur D. I1ttle, Inc., 25 Acorn Park, Cambriage, Massachusetts 02140
} 
total Intensity of aroma (TTA) and is the Intensity volue used in all subsequent plots.

Analytical test8. Undiluted exhaust gas samples in volumes as high as 500 liters were passed through the adsorbent traps. The chemical compounds retained on the traps, mainly high molecular velght organlc specles, were then removed by solvent extraction. Samples of the extract (total organic extract, TOE) were then analyzed by liquid chromatography. The chromatographic separation produced three diftinct peaks representing three clasees of chemlcal compounds: the paraffins which ire nonodorous, and the aromatics and the oxygenated compounds which are primarily responstble for the odor of the exhaust gases. The aromatic specles result from the aromatic content of the fuel while the oxygenate compounds, which are products of partial oxtdation, consiat primarily of h1gh molecular-welght alcohols, adehydes, ketones, and methoxy compounds. Low and h1 gh-resolution mass spectrometry of the aromat1c (LCA) and oxygeneted (ICO) fractions can give further insight into the chemical composition of these general classes, but is quite time-consuming and generally not warranted.

\section{Test Facility}

Combustor. A single-can combustor from a J57 engine was installed in a closed-duct test facility capable of supplying nonvitiated combustion alr at pressures up to 10 atmospheres and temperatures to $600 \mathrm{~K}$. The standard J-57 fuel manifold containing 6 Duplex nozzles was used for most of the tests. Fuel flowg to the primary and secondary nozzles were metered and controlled separately.' The combustor liner was housed in a 30.3 centimeter pipe as shown in Plgure 6.

Instrumentation. The instrumentation for this investigation consisted essentially of 8 flve-point chromel-alumel thermocouples and of 8 five-polnt steam-cooled sample probes positioned as shown in Plgure 6. The individual sample probes were connected to a conmon mantfold. Exhaust-gas samples passed from the probes to the instruments through 1. 9 centimeters diameter stainless-steel tubing approximately 15 meters long and steam-heated to maintain a gas temperature of about $420 \mathrm{k}$.

At the montoring station, the exhaust-gas sample was split into two streams. One portion was fed to the on-line gas-analysis console capable of measuring concentrations of total hydrocarbons, carbon monoxide, carbon dioxide, and oxides of nitrogen. Values of combustion inefficlency were derived from these measurements. A description of the instrumentation console is found in reference 6 .

The second portion of the exhaust-gas stream was passed through a heated filter to remove soot particles and was processed for odor measurements as shown in figure 1.

\section{Test Program}

The test program, shown in flgure 7, was set up to determine the effect on odor intensity of the following variables: 1) combustor-1nlet conditions, 2) fuel composition, 3) combustor modifications.

At the beginning of the lnvestigation 1t was felt that the primary problem with odor emlssions would occur at the lale condition where combustion efficlency is known to be low. In prellolinary testa where combustor-1nlet conditions vere varied parametrically it was found that essentially two levels of odor intensity could be readily distinguished by the panel: a high level of odor Intensity associated with low-efficlency operation and a low level of intensity associated with high-efficiency operation. Thus the combustor-inlet conditions shown in $118-$ ure 7 were selected for the maln part of the probram.

In order to determine the effect of fuel composition on odor, several other fuels besides the standard ASTM A-1 Puel were tested. The fuels were selected to give a vide range in volstility and aramatic content.

Combustor modffications vere limited to changes In the mode of fuel injection. For effective evaporation and mixing of fuel and a1r, good fuel atomlzation 18 necessary. At idle, fuel flovs are so low that, even when only the primary fuel passage of the conventional Duplex nozzle is used, poor fuel, atomization results. In a previous investigation $(7)$ It hed been found that substantial Increases in combuation efficlency at 1dle can be realized by the use of an alr-assisted fuel nozzle. In an alrase1sted nozzle fuel flows through the primary passage of the Duplex nozzle while atr from an auxillary compressor flows through the secondary passage, thus helping to atomize the fuel spray. In addition to the Duplex nozzles, a set of Simplex nozzles sized to cover the range of fuel flows encountered was tested.

\section{Procedure}

At each test condition, after combustor operation had been stabilized, exheust gas was presented to the panel in a series of 5 concentrations, each approximately twice the preceding level. Each panel1st Independently recorded the total intensity of the odor and the primary odor character notes. This required about 2 to 3 snlffa and less than $30 \mathrm{sec}$ onds. A pause of several minutes between successive presentations belped to prevent sensory fatigue. After completion of one dose-response series in order of increasing concentrations, the tests were repeated w1th the same set of concentrations presented in random order. The tests were generally replicated on the following day.

At each concentration the 1ntensity readings recorded by each of the 4 panelists were averaged and the average values plotted against concentration on a semi-logarithmic scale as shown in figure 5 . The intensity of aroma at a dilution of 1000:1 (TIA) is the messure of intensity used in ail subsequent plots.

While the sensory tests were proceding, samples of the undiluted exhaust gas were collected in the adsorbent traps for subsequent chromatographic analysis at A. D. Little, Inc. facility in Cembridge. At the same time pertinent combustor operating data including on-Iine gas analysis measurements were recorded on the Lewis data acquisition system.

\section{Results and Discussion}

The scope of the present investigation was to obtain odor data over a range of turbojet engine combustor operating conditions with several different fuels and with several combustor modifications to see if the odor data could be correlated with 
cambustion efficlency. The technique employed vas essentially that developed by A. D. Little, Inc. for Diesel exhaust. To achieve these results three separate sets of data vere taken: 1) cambustor perPormance data, Lnclualng gas anolysis of the exhaust gas to provide combustion efficlency values, 2) sensory odor tests conducted by the human panel, 3) analytical tests carried out with samples of und livited exhaust collected on adsorbent substrates.

In a number of cases the extracts from the traps were relntroduced into the odor chamber in concentrations approximating the dilution ratios or18inally presented to the odor panel. The odor intensities of the reconstituted exhaust bamples correlated with the odor intensities of the original exchaust.

Effect of combustor-inlet conditions. In the early phases of the investigation cambustor-inlet conditions were varled parametrically to establish a range of odor intensities that could be readily distingulahed by the panel. The results of these tests, conducted with ASTM A-1 fuel are shown in P1gure 8 where odor Intensity at a dilution ratio of 1000:I (TIA) is plotted against the logerithm of combustion Inefficlency, as determined by gas analys18. Odor intensity correlated well with cambustion inefficiency, and as a result the remaining tests were conducted at the combustor-1nlet cond1tions shown in figure 7. Conditions 1 and 3 represented low and high efflciency operation, respectively. EPficiencies at condition 2 generally fell between those of conditions 1 and 3 .

In figure 9, odor intensity (TIA) is plotted agalnst the logarithm of the concentration of the oxygenated species (ICO), in microgrems per I1ter of exhaust, as determined by chromatographic anelysis. A good correlation between TIA and LCO was obtained, suggesting that anglytical tests might eventually replace the more cumbersome sensory tests conducted by the odor panel. Good correlations were also obtained between TIA and the concentrations of the aroutic species (LCA). However, since the trends were similar, only the ICO plots are presented in this report.

Effect of combustor modifications. Combustor modifications cons1sted only of changes in the mode of fuel injection since emphasis was placed on idle operation and proper fuel atomization 18 known to be a critical factor at idle operation. The results presented in figure 10 show that a substantial reduction in odor intensity was achieved through the use of an air-assist nozzle at combustor-1nlet conditions where low efficiency and hence high odor Intensity was obtalned with the standard Duplex nozzle. At combustor-inlet conditions where eff1clency with the standard Duplex nozzle was close to 100 percent, no additional reduction in odor intensity was achieved with the air-assist nozzle. For comparison, tests were made with a set of Simplex fuel nozzles, sized to provide fuel flow over the entire flow range with the existing pump capacity. As a result nozzle pressure drops were very low for the low fuel-flow conditions while at the higher fuel flows higher nozzle pressure drops with resultant good fuel atomization were obtained. At the high fuel-flow condition h1gh values of combustion efficleacy with correspondingly low velues of TIA were attalned while at the low fuel-flow conditions low values of efficlency and corre epondingly high velues of odor intensity resulted. The regression
IInes shown on figures 8 and 10 were computed from all the data obtalned with ASTM A-1 fuel, indicating that the correlation 18 valid whether the ineff1clency 18 caused by adverse combustor-1nlet cond1tions or by fuel apray charecteristica.

The corresponding plot of LCO versus TIA, presented in figure 11 , again shows good correlation between odor intensity and the concentration of oxygenates. The regression IIne was computed from all the date obtalned with ASTM A-1 fuel.

Effect of fuel properties. Four $P$ fuels in adaition to the standard ASTi A-I fuel were selected to give a wide range in volatility and composition. Natural gas was included because it is a gas and consibts primarily of the low molecular-weight methane while the other fuels are liquids containing higher molecular-weight compounds. The data presented in Pigure 12 show that the correlation between odor intensity and inefficlency established for ASTM A-1 fuel is not oppropriate for all fuels. Eorever, the date for $\sqrt{\mathrm{P}-4}$ and for the high-aromatic JP-5 seem to correlate reasonably well with the regression line estabilshed for ASTM A-1 fuel. These regults are not too surprising since these three fuels are somentat similar in character while isoctane and natural gas differ greatly from them both in composition and volatility.

The relation between concentration of oxygenates and odor Intensity is shown in figure 13. In contrast to the efficlency data, a good correlation between TIA and LCO was obtalned, further conf1rming the potential of using ICO as a measure of odor intensity.

\section{Analytical Liquid Chromatograph (ALC)}

The data presented in flgures 11 and 13 show that the correlation between the concentration of oxygenates, in micrograms per liter of exhaust, and odor latensity, established for ASIM A-1 fuel, also applies for the case where nozzles as well as fuel composition were the variables. This finding is in good agreement with the large amount of data whlch A. D. Little, Inc. has collected with Diesel exhaust. This earlier success had led them to search for an instrument wh1ch could perform the se analytical functions in an automatic manner, thus greatly speeding up the process of obtaining odor 1ntensity data. Such an instrument has now been developed by A. D. Little, Inc. to the prototype stage.

The basic measurement technique which is similar to the manual method depends on chromatographic geparation of the aromatic (ICA) and the oxygenate (ICO) Iractions for subsequent measurement by an ultraviolet absorbent detector. The magaitude of the detector response 1s proportional to the quantity of LCA and LCO eluted from the column so that, with proper callbration, the concentrations of aromatics and oxygenates present in the original. undiluted exhaust can be computed. A schematic diagram of the prototype ALC system is presented in figure 14 and a typical chromatogram is shown in figure 15.

A more detalled description of the instrument which was developed entirely in the A. D. Little, Inc. Diesel program is given in reference 1. Although the Instrumental method has had only limited experimental verification, the results have been suff1clently encouraging to warrant 1 t 6 continulag development and usage as a means of supplementing sensory 
odor data. Eventually it could be used as a fleld instrument to minimize the need for human odor panels and to expedite greatly the process of collecting data on oior intenalty.

\section{Sumary of Resulta}

An Invest1gation was conducted to deternine the 1ntensity and character of the odor of exhaust gas from a aingle-can J57 combuator operating at simulated idle conditions with a number of different fuels and wh several combustor modifications and to correlate the odor data wth combustion efficlency. The following results were obtained:

1) A group of human belnge can be tratned to recomize and to identify differences in odor intensity and character when exposed to varylng concentrations of diluted exbaust gas under controlled conditions.

2) Intensity of the odor of exhaust decreased as combustion efficlency increased. This was essentially true whether 1ncreases in combustion efficlency were brought about by combustor modifications or by operation at less severe combustor-inlet conaltions. No correlation between odor intenalty and combustion efflclency wes obtained with verlations in fuel composition. Use of an alr-essisted fuel nozzle for 1dle operation was especially effective in reducing odor intensity.

3) The malodorous congtituents of exhaust gas can be collected by passing large volumes (about 500 Iiters) of the gas through specially-prepared adsorbent traps from which they can subsequently be extracted by means of solvents. Chromatographic separation of the extract from these adsorbent traps has shown that the principal malodorous epecies in jet exhaust are the aromatic (fuel-related) and the oxygenated (partially burned) Iractions. Chromatographlc analysis of these extracts has also shown that the concentrations of the oxygenated specles, in micrograms per liter of exhaust, correlate well wth odor intensity as determined fram sensory tests.

\section{References}

1. Kendall, D. A., and Levins, P. L., "Odor Intenofty and Characteristization of Jet Exhaust and Chemical Analytical Measurements," ALL74443, NASA CR-121259, Mar. 1973, A. D. Little, Inc., Cambridge, Mass.

2. Anon., "Chemical Identification of the Odor Components in Diesel Engine Exhoust," C-70131, C-70132, 1969, A. D. Little, Inc., Cambridge, Mass.

3. Anon., "Chemical Identification of the Odor Components in Diesel Engine Exhaust," C-71407, C-71407-2, 1970, A. D. Little, Inc., Cambridge, Mass.

4. Anon., "Chemical Identification of the Odor Components in Diesel Exhaust," $A[x-62561-5$, 1971, A. D. Ifttle, Inc., Cambridge, Mass.

5. Anon., "Analysis of the Odorous Components in Diesel Exhaust," AII,-73686-J, 1972, A. D. Ifttle, Inc., Cambridge, Mass.

6. Ingebo, R. D., and Norgren, C. T., "Effect of Primary-Zone Water Injection on Pollutents from a Combustor Burning Liquid ASTM A-1 and Vaporlzed Propane Fue1s," TN D-7293, 1973, RASA, Gleveland, Ohio.

7. Briehl, D., and Papathakos, I., "Use of an AirAssist Fuel Nozzle to Reduce Exhaust Emissions from a Gas-Turbine Combustor at Iole Conditians," TN D-6404, 1971, NASA, Cleveland, Ohio. 


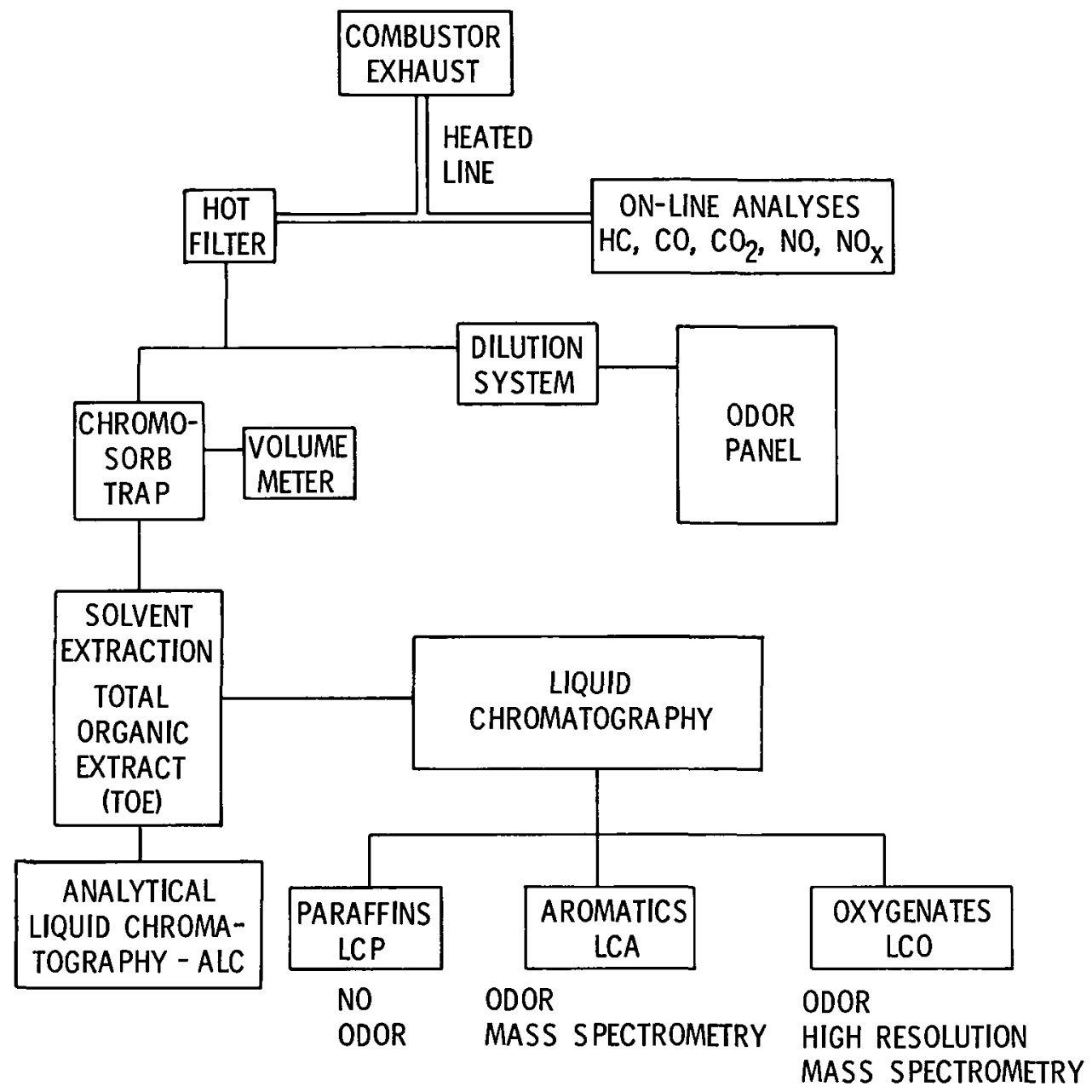

Figure 1. - Exhaust-odor characterization technique. 


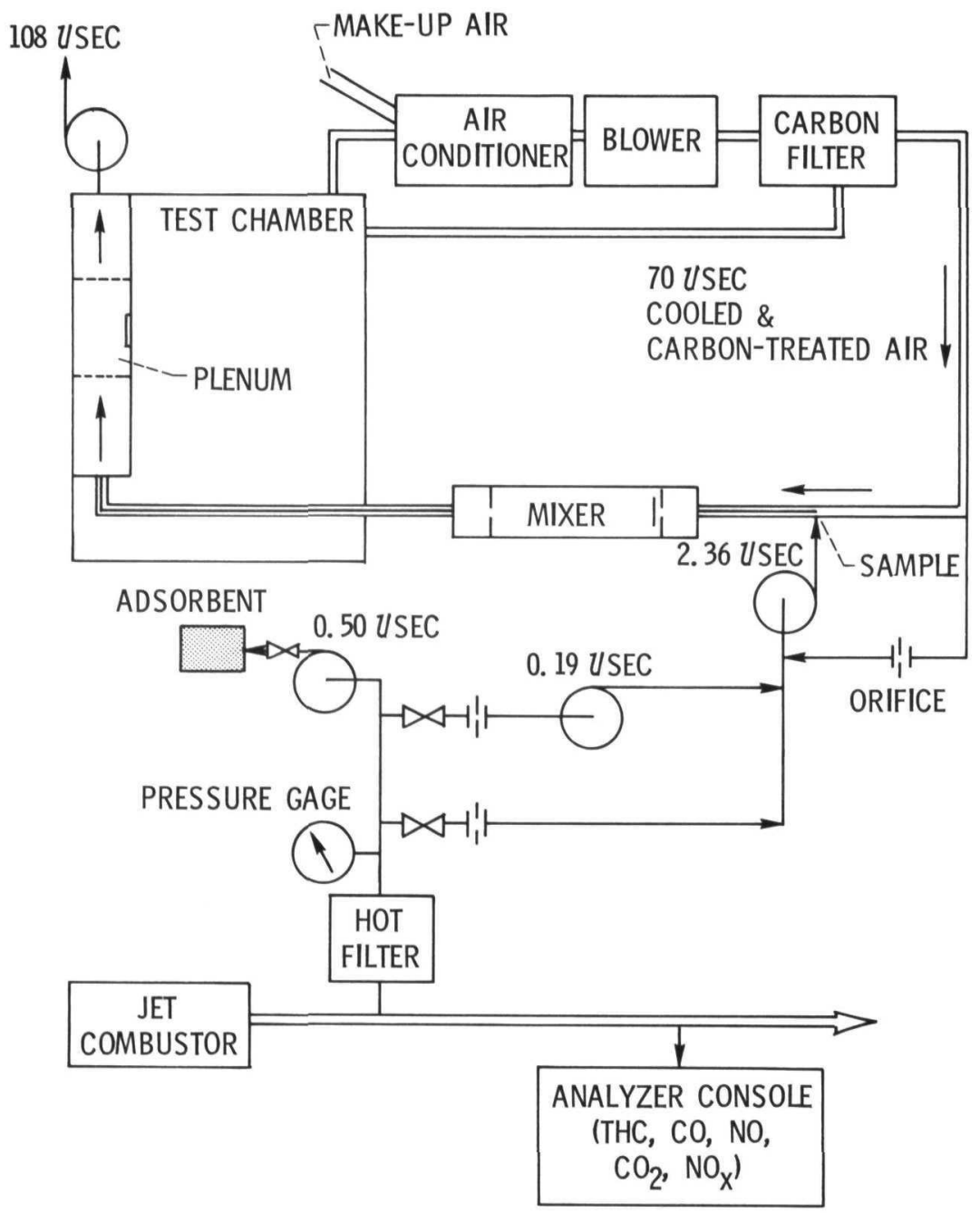

Figure 2. - Schematic arrangement of equipment for NASA odor test facility.

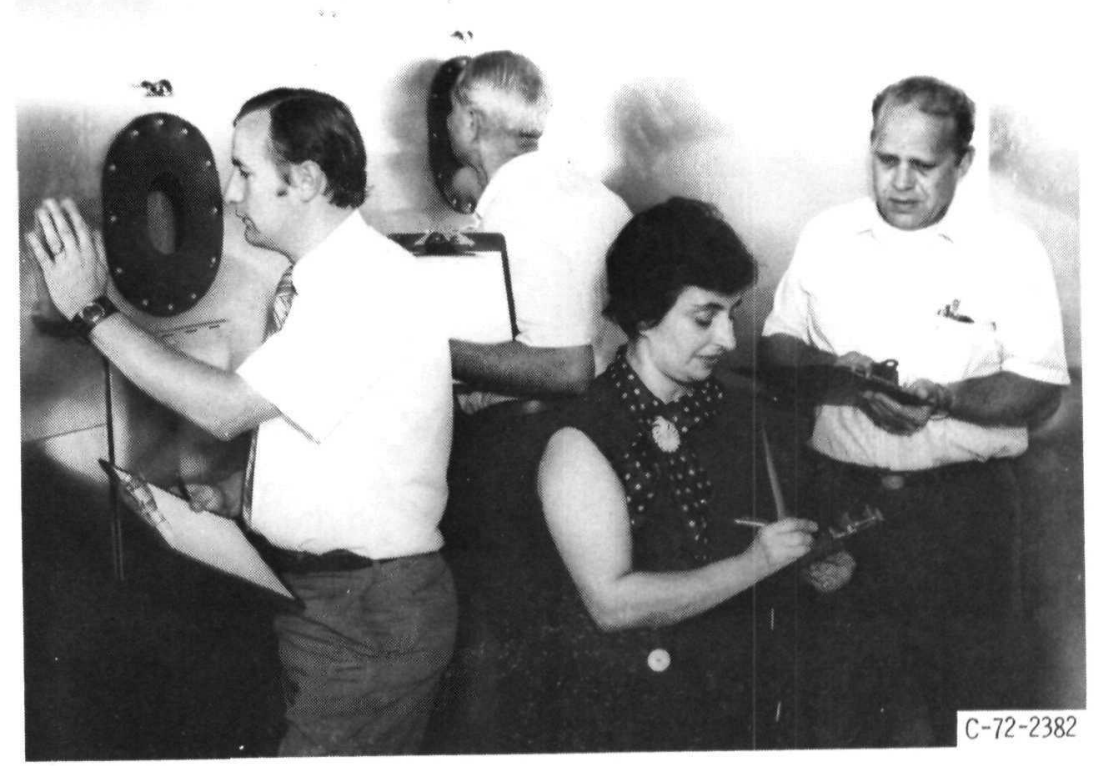

Figure 3. - NASA panel inside odor test facility.

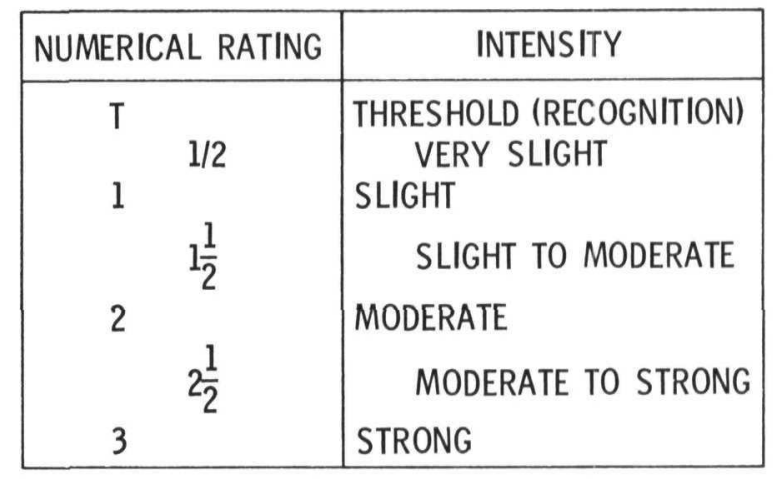

Figure 4. - Odor intensity scale. 


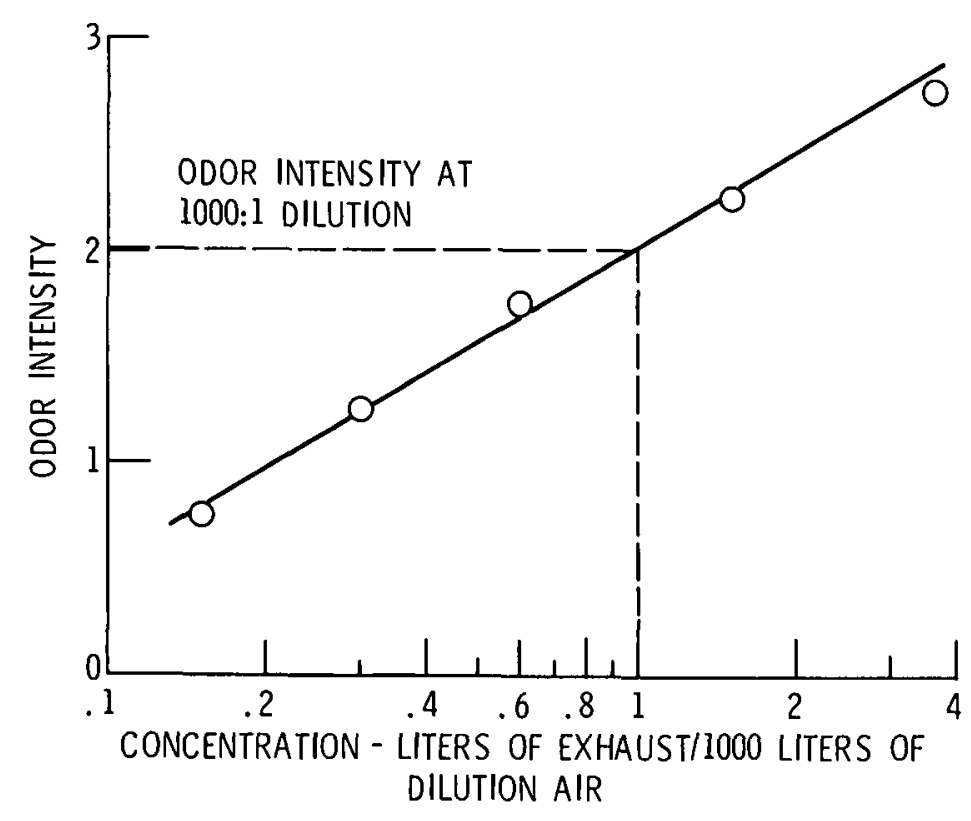

Figure 5. - Typical dose response curve.

\section{- TOTAL TEMPERATURE \\ $\square$ GAS SAMPLE PROBE \\ $\triangle$ STATIC PRESSURE}

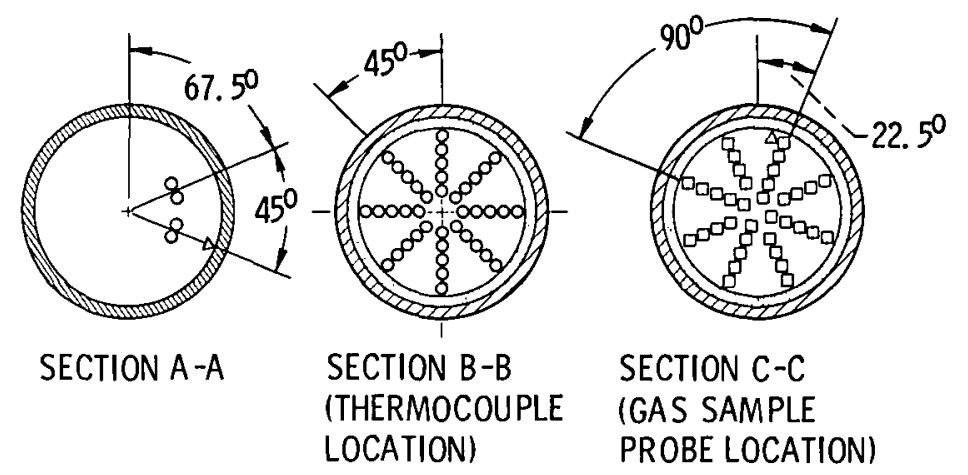

(a) INSTRUMENTATION STATIONS.

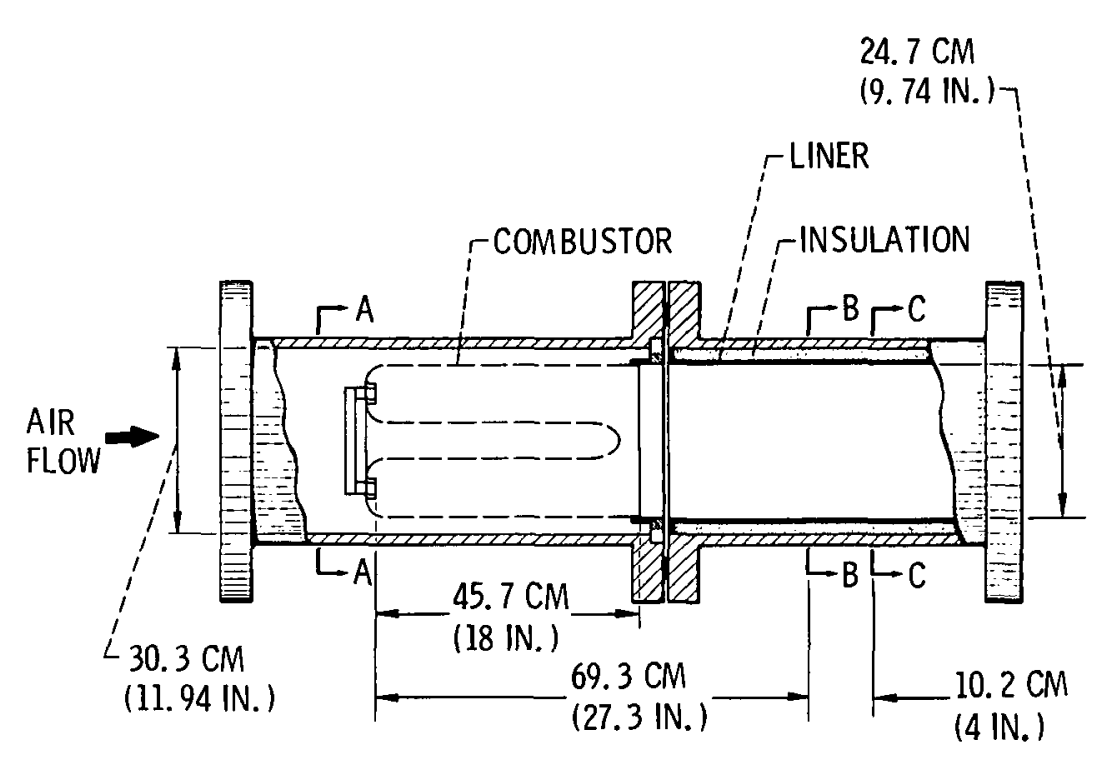

(b) LOCATION OF INSTRUMENTATION AT EACH STATION.

Figure 6. - Combustor test duct. 


\begin{tabular}{|c|c|c|c|}
\hline \multicolumn{4}{|c|}{ TEST CONDITIONS } \\
\hline CONDITION & $\begin{array}{l}\text { COMBUSTOR- } \\
\text { INLFT } \\
\text { PRESSURE } \\
\text { ATMOS }\end{array}$ & $\begin{array}{l}\text { COMBUSTOR- } \\
\text { INLET TEMP, } \\
0_{K}\end{array}$ & $\begin{array}{c}\text { FUEL-AIR } \\
\text { RATIO }\end{array}$ \\
\hline $\begin{array}{l}1 \\
2 \\
3\end{array}$ & $\begin{array}{l}2 \\
2 \\
4\end{array}$ & $\begin{array}{l}150 \\
150 \\
240\end{array}$ & $\begin{array}{r}0.008 \\
.016 \\
.013\end{array}$ \\
\hline
\end{tabular}

ASTM A-1

JP-5 (HIGH AROMATIC)

$J P-4$

ISOOCTANE

NATURAL GAS

COMBUSTOR MODIFICATIONS

DUPLEX FUEL NOZZLE

AIR-ASSISTED NOZZLE

SIMPLEX FUEL NOZZLE

Figure 7. - Test program.

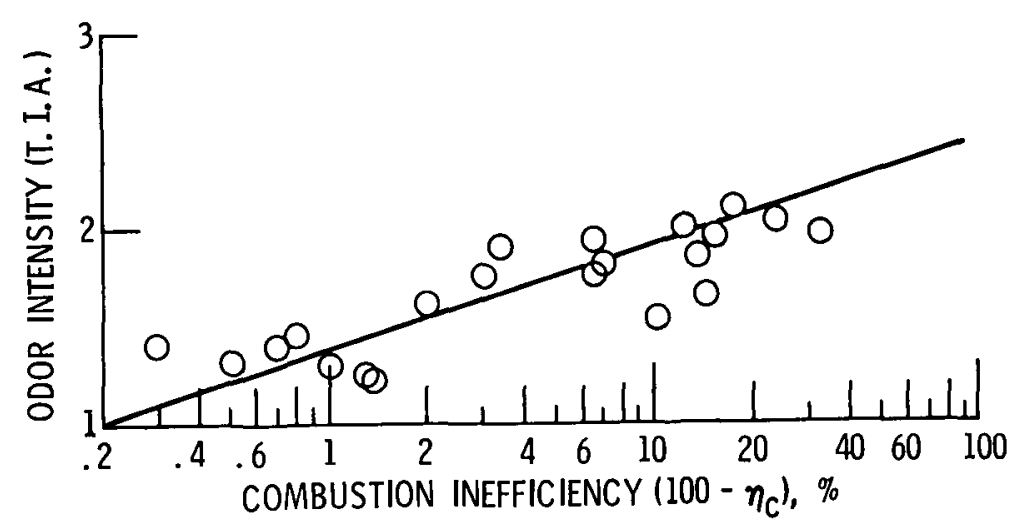

Figure 8. - Correlation between odor intensity and combustion inefficiency. ASTM A-1 fuel; variable: combustorinlet temperature and pressure, and fuel-air ratio.

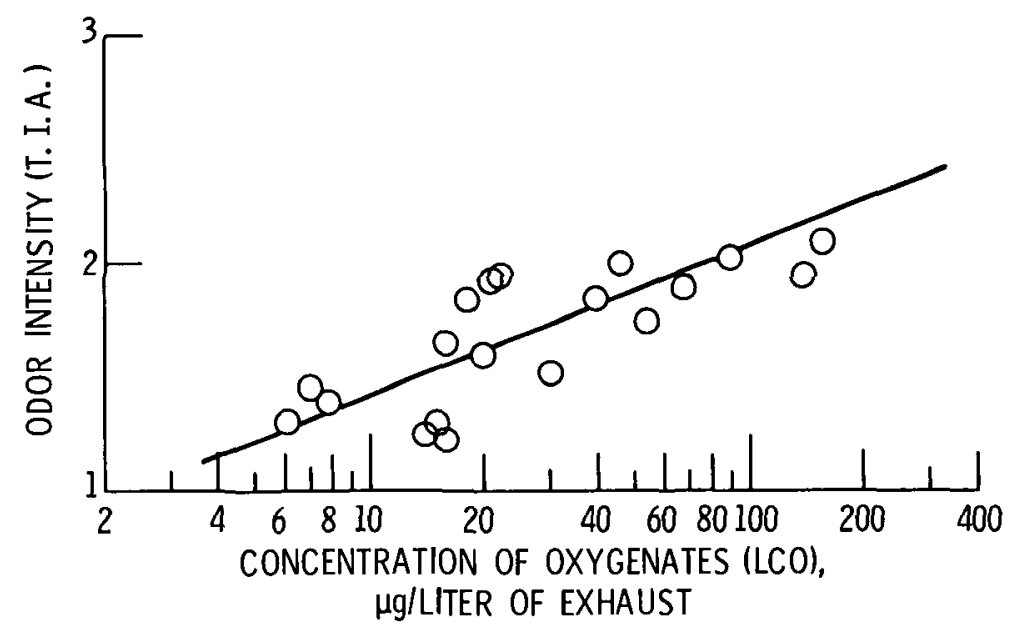

Figure 9. - Correlation between odor intensity and concentration of oxygenates. ASTM A-1 fuel; variable: combustorinlet temperature and pressure, and fuel-air ratio. 


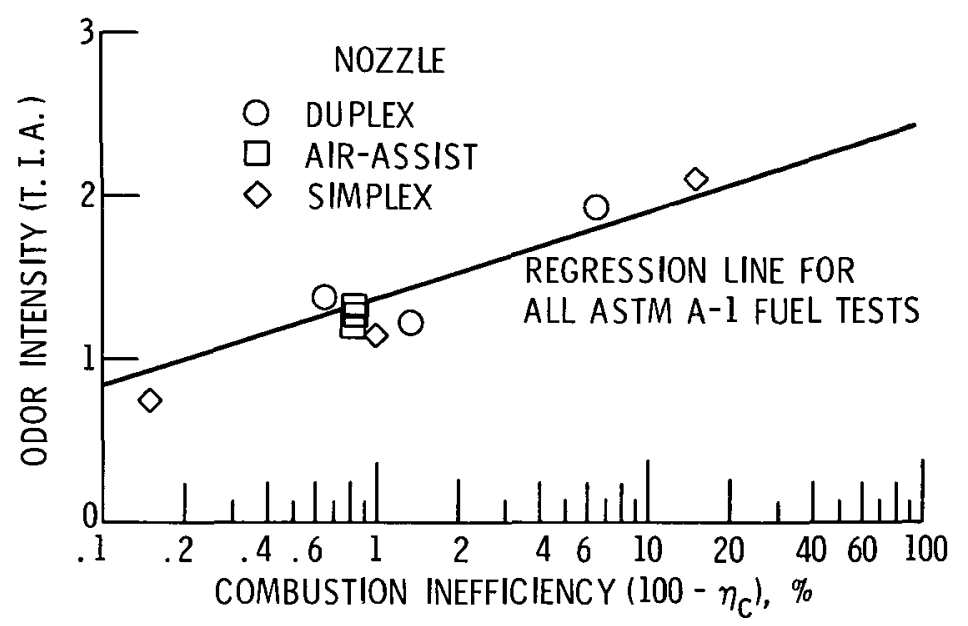

Figure 10. - Correlation between odor intensity and combustion inefficiency for various fuel-nozzle modifications. Fuel, ASTM A-1.

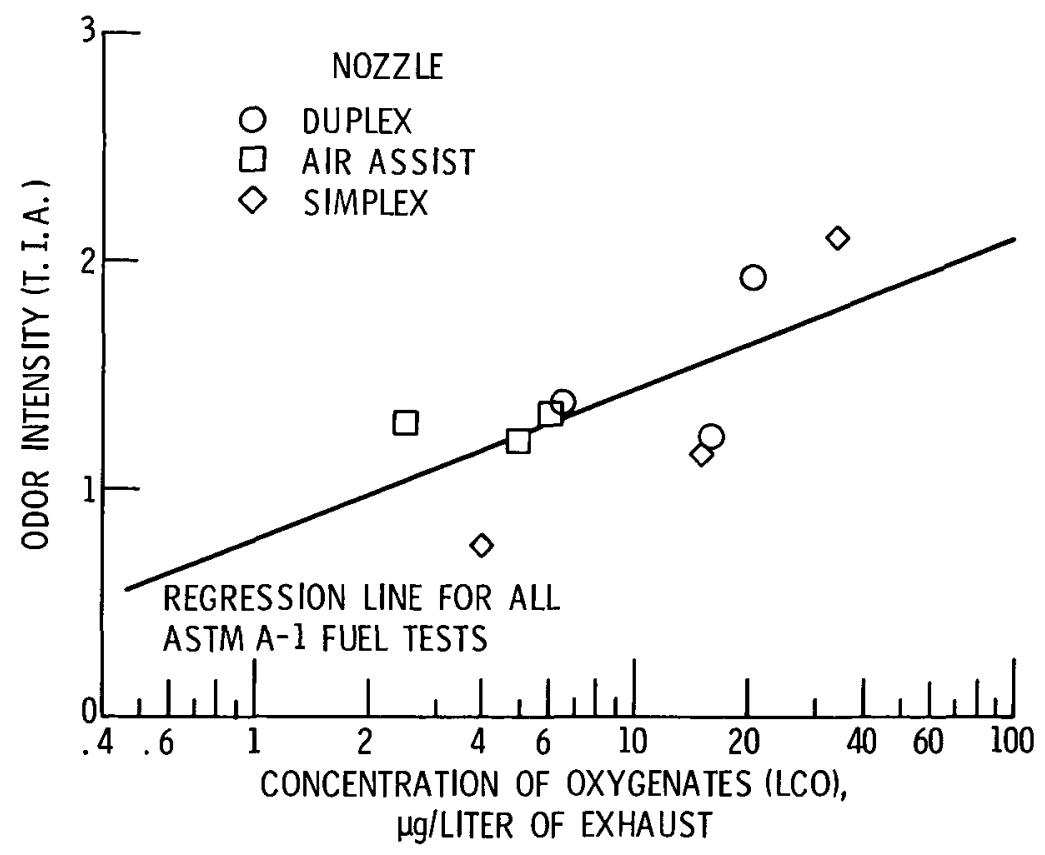

Figure 11. - Correlation between odor intensity and concentration of oxygenates for various fuel-nozzle modifications.

Fuel, ASTM A-1. 
FUEL

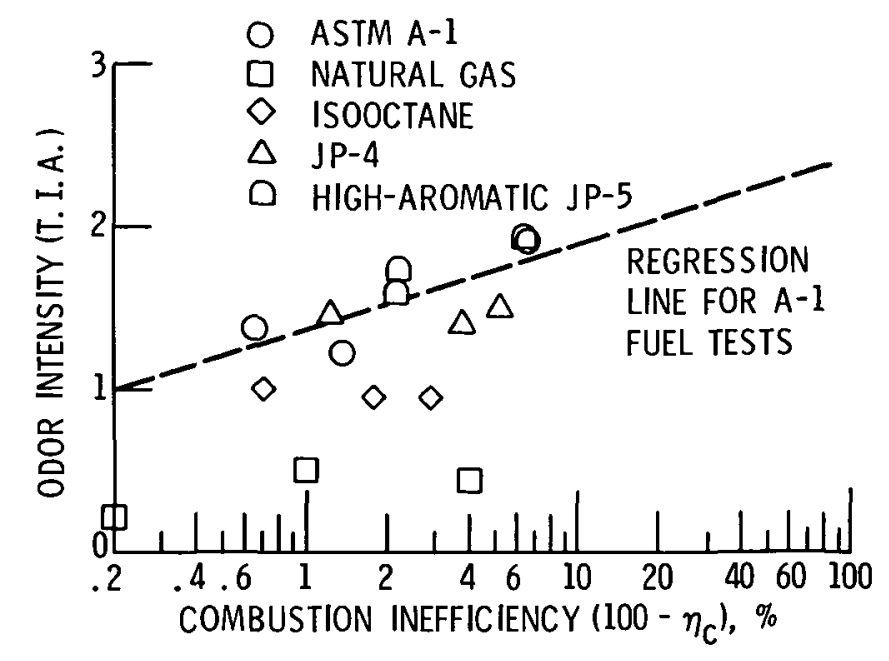

Figure 12. - Correlation between odor intensity and combustion inefficiency for various fuels.

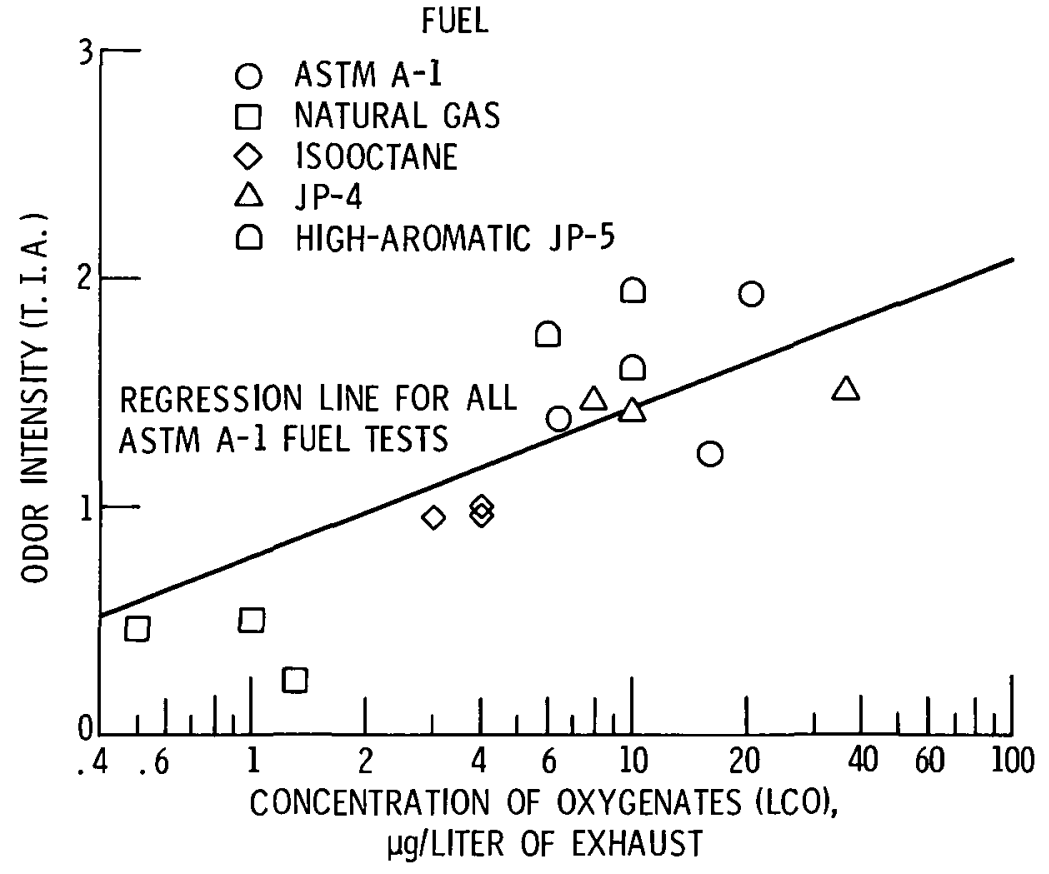

Figure 13. - Correlation between odor intensity and concentration of oxygenates for various fuels. 
35\% METHYLENE CHLORIDE

IN HEXANE

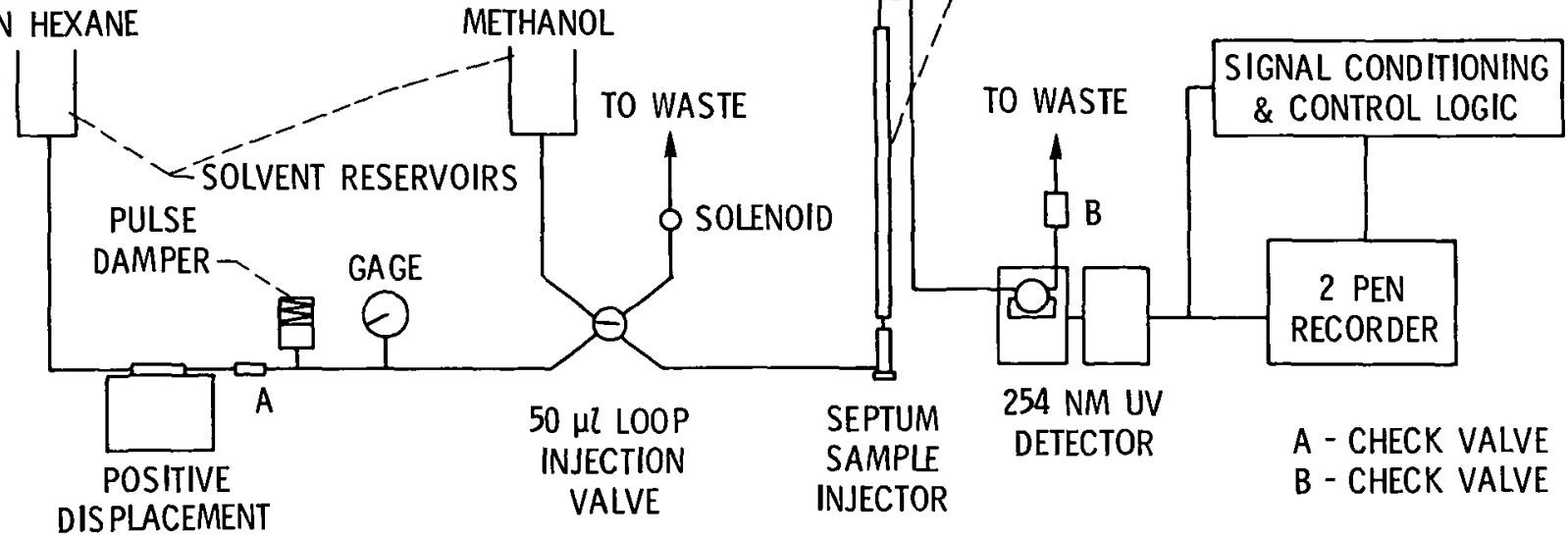

MINI PUMP

Figure 14. - Analytical liquid chromatograph (ALC) prototype system.

0
0
0
1
1
$1=1$

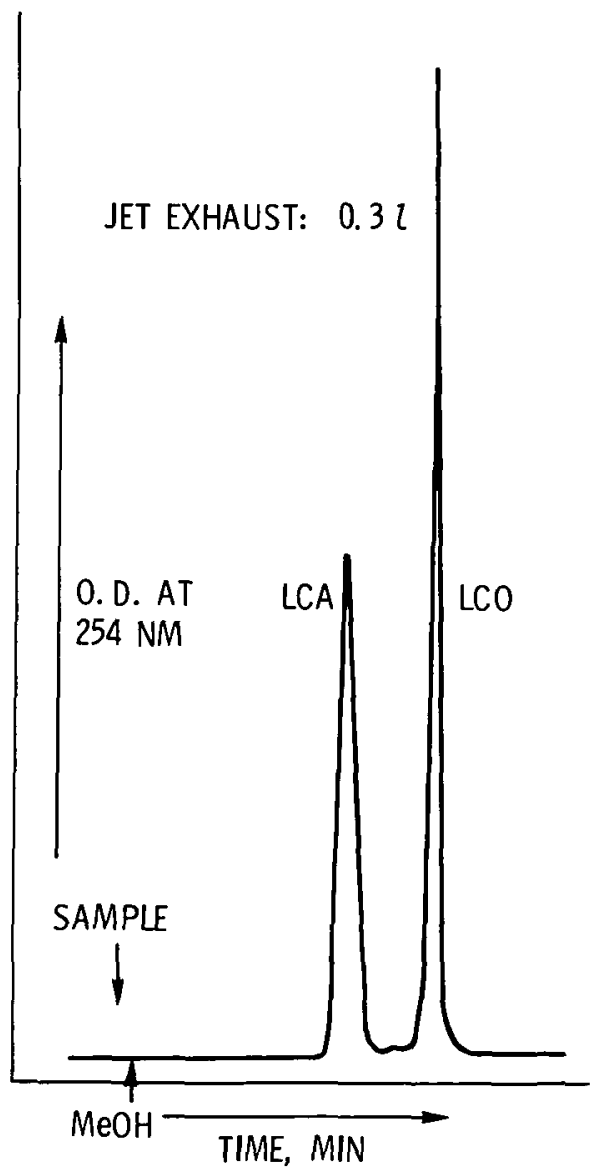

Figure 15. - Typical chromatogram of jet exhaust T. O.E. sample. 